\title{
História e revolução A Revolução Francesa e uma nova idéia de história
}

\author{
Renato Janine Ribeiro •
}

RENATO JANINE RIBEIRO é professor de Filosofia Politica do Departamento de Filosofia da FFLCH da USP e autor de "A etiqueta no Antigo Regime", "Ao leitor sem medo" (ambos editados pela Brasiliense) e "A marca do Leviatã" (Ática).

(*) Este texto é parte de uma conferência pronunciada no Colóquio de 1987 da Associação Nacional de Pós-Graduação em Filosofia - ANPOF, por mim organizado e que teve por título 1789 - Sombra e Luzes. O texto integral desta e das demais conferências sairá em livro pela Companhia das Letras, em 1989. (1) Stendhal, La chartreuse de Parme,
cap. 7 .
Ainda tem pertinência pensar o acontecer histórico mediante as revoluções? Esta pergunta nasce de uma constatação elementar: há dois séculos que o fato histórico fundamental é a revolução. Enquanto esperança ou enquanto medo, a revolução aparece aos homens como a linha divisória, a promessa ou ameaça que decidirá de suas vidas. Isso vemos perto de nós, no confronto de integralistas e comunistas nos anos 30 , ou no de progressistas e reacionários às vésperas de 1964. Muito apropriadamente, muito lúcido, Pedro Aleixo - o udenista que foi vicepresidente de Costa e Silva - caracterizou o movimento militar de 1964, não como "revolução", mas como contra-revolução. E lemos isso já em Stendhal, no seu romance de 1830, $O$ vermelho e o negro: os aristocratas que freqüentam o palacete de la Mole têm pavor da revolução. Tudo o que sucede à sua voita parece, já, antecipá-la - e o máximo que farão, prevê sarcástica a jovem Mathilde de la Mole, é subir heroicamente os degraus da guilhotina. Por isso mesmo a nobreza reavalia a sua própria atitude, bela, fulgurante, dos anos 1780: a liberdade de costumes e de dizeres que cntão viveu agora the parece, retrospectivamente, ter despertado, talvez causado, a revolução. Por isso nada diz que tenha brilho, mata a conversação, para não se matar enquanto classe. 0 único assunto brilhante a se tratar nos salōes de 1825, afirma Stendhal, é a música de Rossini.

Em outra obra de Stendhal, $A$ cartuxa de Parma, o príncipe se irrita ao ouvir o moço e estouvado Fabrício desenvolver teses contra-revolucionárias, que são as de Joseph de Maistre e de Bonald; o que o irrita é o brilhantismo do rapaz: "Um homem de espírito bem pode seguir os melhores princípios [ = os reacionários] e até mesmo de boa-fé - por algum lado ele continua sendo primo-irmão de Voltaire e Rousseau"(1). O espírito está em conflito com a dominação reacionária. Esprit, palavra difícil, que traduzimos muitas vezes por espírito, mas que remete igualmente bem ao engenho, ao pensamento barroco - só que, aqui, somado às Luzes, modificado por elas. O que aconteceu foi que nessas décadas de passagem do século XVIII ao XIX, do Ancien Régime aos regimes que se buscam, o brilho tornou-se perigoso, subversivo - e isso porque, de diversão apenas prazerosa, passou a ser capaz de modificar o mundo. Porque a inteligência se engatou numa idéia nova, que conquistou a Europa e rodeia o mundo - a de revolução. "Um fantasma", dirá Marx em 1848, que atemoriza o papa e o czar.

Termina, no século XVIII, uma idéia de história enquanto elenco de exemplos. Falece uma idéia de história que se subordina ao cíclico, para emergir uma de inovação. Sejamos mais precisos: se na história anteriormente concebida havia repetição, era porque de algum modo ela revelava; o ciclo era, simplesmente, o das constâncias da natureza humana. Por isso, o trabalho de fazer história consistia, quando dava a pensar, em apontar para o melhor conhecimento da natureza humana. Tomemos os moralistes do século XVII francês, esses que devassam os escaninhos da alma; mais especificamente, La Bruyère: o seu laboratório é a observação próxima, e basicamente a do homem de corte, do homem em cuja vida é maior a parte do que é vão, do que não responde ao interesse (ou ao interesse bem compreendido), e portanto maior a parte do que re- 
sulta da mera fantasia, da imaginação, - em suma, maior é o que se descola do interesse. Pois esses moralistes, se o lugar em que mais lêem o homem é na corte, descortinam ainda um outro campo de leitura: a história. A corte thes dá o melhor espaço de observação, porque é onde se extrema a vaidade, a vanidade, que são a essência da atividade mental humana ${ }^{(2)}$. Por isso.

"Um velho que viveu na corte, que possui um grande senso [ou sentido], e uma memória fiel, é um tesouro inestimável; está repleto de fatos e máximas [já temos aqui indicada a idéia de que o importante é a máxima que se extrai do fato, a moral que se tira do acontecido]; nele [no tesouro] se encontra a história do século, revestida de circunstâncias curiosíssimas, e que não se lerão em livro algum; com ele [o tesouro] se aprendem regras para a conduta e os costumes que são sempre seguras, porque estão fundadas na experiência"(3). Observação que não é experimental, embora La Bruyère fale em experiência: porque esta não é produzida, não está cercada pela preocupação de controlar o maior número de variáveis. A experiência é, sim, acolhida. Quer dizer também que não é passiva, mas tampouco foi induzida ou controlada. Hobbes a identifica com a prudência, com a sabedoria: é algo que nós conseguimos enquanto procuramos outra coisa (Leviathan, cap. 13), é vivência, experiência de vida; diz ele:

"Quando os pensamentos de um homem, que tem em mente um desígnio, percorrem grande número de coisas, e observam como elas concorrem para tal desígnio; ou para que desígnio podem concorrer: se essas suas observaçöes nảo forem banais, ou corriqueiras, este engenho seu (wit) é chamado PRUDÉNCIA; e depende de muita experiência, e memória de coisas análogas, e de suas conseqüências que ele viu acontecer"(4). A experiência está entre o wit e o esprit: é do homem do mundo, do homem que sabe o seu mundo (isto é, corihece a sociedade) - não de um cientista, a manipular instrumentos.

Mas esse homem, que tem na corte um quase-laboratório, verá na história algo que se situa entre a descoberta (desempenhando, pois, papel análogo ao da experiência pessoalmente vivida) e a contraprova (confirmando, em maior extensão, à distância, o que foi experimentado no campo de prova, na corte). Ler a vida dos varōes ilustres, remeter a Plutarco ou a Flávio Josefo, é ver a história como reiteraçāo de constâncias. Essa história, porque fornece exempla, dá a pensar: porque serve de estoque ao conhecimento da verdade. Citemos o Quixote através de Pierre Menard, o personagem que Borges inventou para reescrever Cervantes (Ficciones, 1941): "a verdade, cuja mãe é a história, êmula do tempo, depósito das ações, testemunha do passado, exemplo e aviso para o presente, advertência do porvir"(5). A mesma enumeração, se escrita em começos do século XX, - diz Borges - significaria subordinar a verdade ao pragmatismo, fazê-la derivar do tempo e das necessidades humanas ${ }^{(6)}$; mas no século XVII, escrita por

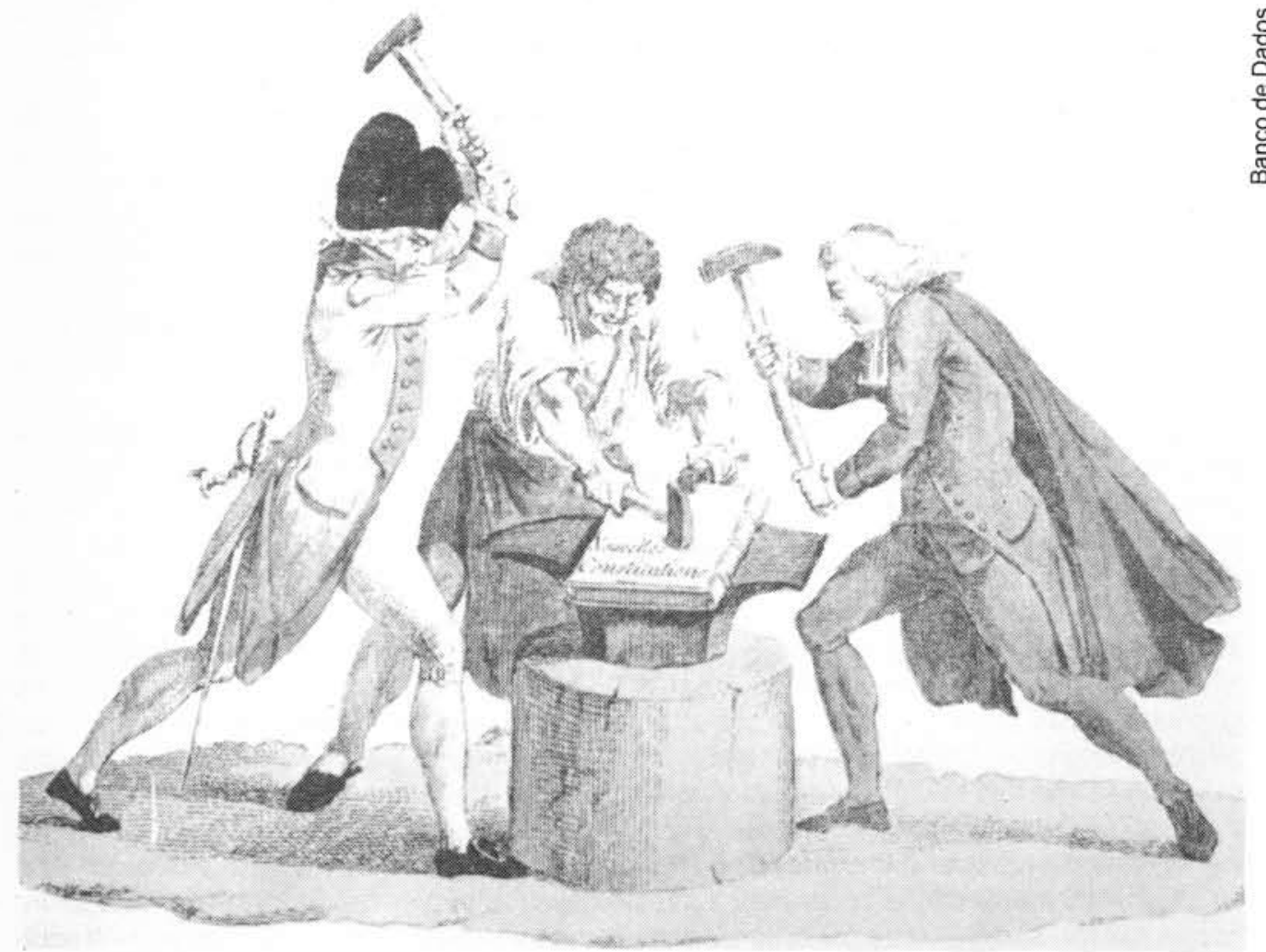

(2) A este respeito é significativa uma passagem pouco comentada de Thomas Hobbes, que encerra o cap. 8 de seu Human nature (1640) - a definiçăo que ele dá de paixăo:

"8. Passions. In the pleasure men have, or displeasure from the signs of honour or dishonour done unto them. consisteth the nature of the passions, whereof we are to speak in the nezt chapter" (começando o capitulo seguinte, justamente, com a definição guinte, justamente, com a definição glory'). Se, como é frequeente no pensamento inglês, Hobbes atribui ao prazer e desprazer papel importante nas paixóes, o mais notável nessa passagem é, porém, o destaque dado à honra ou desonra que recebemos óos outros. Em última análise, a definição das paixōes proposta no cap. 9 desse livro as entenderá a partir da glória ou desonra que sentimos. É dizer que esse complexo passional honra-desonra é o que melhor exprime certos traços distintivos das paixōes em geral: o fato de ser impossível uma percepçáo rigorosamente adequada da 'realidade', - o fato de dependermos, nelas, da opiniăo alheia, - a maneira como, assim, se introduz a polftica na psicologia: porque nossas paixôes já se explicam a partir da forma como o outro domina nossa vida mental.

(3) La Bruyère, Les caractères, cap. "De lhomme", § 118 - p. 288, da ediçāo Garnier Flammarion.

(4) Leviathan, pp. 137-38 da ediçáo Penguin (1968).

(5) D. Quixote, livro I, cap. 9.

(6) Jorge Luis Borges, Obras Completas, Buenos Aires, Emecé, 1974 p. 449.

Gravura da época mostrando as três ordens sociais, forjando juntas a nova constituição 
Cervantes, ela apenas retoma o topos antigo, que encontramos - repetido de Cícero - já exposto por La Popelinière no final do século XVI: "o eterno tesouro de exemplos, imagem viva da vida humana, sempre aplicável a todos os tempos, livro dos reis e magistrados, mestra da vida (magistra vitae), elo com a Antigüidade, vida da memória, luz da verdade, testemunho do tempo"(7). La Popelinière, que faz parte de um grupo de historiadores que, anacronicamente, esboça a disciplina que se constituirá mesmo é no século XVIII, critica isso tudo; mas a formulação é boa para entendermos o que seria a história nos séculos que antecederam o XVIII. Sabemos que importava bem pouco, para aqueles historiadores, a verdade dos acontecimentos (ou dos processos) registrados; proponho um porquê: simplesmente porque o importante não era a inteligibilidade do que a história narrava enquanto história - e sim o seu uso para entender-se o ser humano. A história prolongava a experiência; era sua prótese, seu alongamento, sua verificação também; o que contava era a moral que, da história, se tirasse. Por isso ela é "livro de reis e magistrados" - não são esses, os que governam, quem mais precisa de prudência, de sabedoria? A história não é ciência, é material permitindo enformar a prudênsia.

(7) La Popelinière, Idée c'e l'histoire accomplie (1599), p. 22 - cit. in George Huppert, The idea of perfect history. Historical erudition and historical philosophy in renaissance France, Urbana, University of Illinois Press, 1970, p. 21.

(8) A Revolução Ameriçana, embora anterior à francesa, é diferente - tarto que a Constituiçáo que dela nasce não formula uma teoria da soberania: - ato supremo nela previsto, o de mudar o próprio texto constitucional, depende de dois órgăos distintos (as câmaras do Congresso), e ainda da ratificação por tres gislativos estaduais, E existe um pro. cedimento alternativo, é verdade que nunca utilizado nestes dois séculos, o de uma convençăo que seria convo. cade diretamente pelas assembléias estaduais.

Talvez, porém, essa diferença se explique parciaimente porque a Revolução Americana foi uma luta de independència nacional, mais que a derrubada de uma classe dominante nativa. Ou, dizendo de outro modo: a desenvolve desde o final do século XVIII (já, portanto, como soberania popular), revela-se mais vinculada a idéia de luta de grupos, ou mesmo classes sociais, pela hegemonia, enquanto a doutrina anglo-saxónica do quer dizer, dos contrapesos que as diversas instâncias políticas, e mesmo sociais, exercem umas face às outras. Isto significa, primeiro, que uma doutrina do equilinos Estados Unidos que nos países de direito romano (lá o Legislativo, Executivo e Judiciário se limitam, ou, em outro plano, a Uniảo, os estados e os poderes locais); segundo, que mesmo na Gră-Bretanha, onde hoje a Câmara dos Comuns é poder sober. no, este fato pode conviver muito bem com uma doutrina que todos sabem vazia, a do papel "soberano" da Coroa (cuja "prerogative" na verdade se deslocou ao Primeiro-Ministro, Comuns), e que em última análise representa a convicção de que, mais que os artigos de lei escrita, ou que instituiçóes políticas, há um consenso social a conter a hegemonia de um facto, de qualque: pretensão à soberania.

Todos sabemos que no século XVIII se realiza a idéia da história como progresso: chegamos ao vetor, às vezes linear, a um avanço constante e crescente. O que costumamos esquecer é que essa idéia de progresso praticamente coincide com a idéia de revolução - ou meIhor, com uma mudança na idéia de revolução. Porque, se lemos um autor do tempo que precede, como Thomas Hobbes, o que entenderá ele da revolução? Que ela é a dos astros. É notável que Hobbes encerre dois de seus livros, o Behemoth e o Leviathan, ambos de título bíblico (e antitéticos: o primeiro sobre a revolução, o segundo sobre seu remédio, o Estado), tratando dos ciclos que há na história, "as revoluçōes dos Estados": que são as repetiçōes, as voltas que se dá para retornar-se, simplesmente, ao ponto de partida. Falando em revolução circular (Behemoth), em reıolução dos astros acerca do aspecto em que nasce sua teoria (Leviathan), Hobbes ironiza e ridiculariza a astrologia, em favor de uma astronomia na qual o importante é a constância dos movimentos, sua regularidade - e não a dissimetria cios temas natais. E, da mesma forma, aponta a vanidade da conduta subversiva, que só faz repetir-se, não leva a nada: tão fútil quanto a astrologia.

Já nos finais do século XVIII, a revolução faz-se ruptura. Provavelmenie isso se deve a alguns fatores: a revolução vai sendo pensada como forma (uso da violência) - identifica-se com a revolta, e assim inscreve a violência na história, usada para mudar o que existe. Mas isso não seria pensável sem a idéia de que a história é mudança, transformação, idéia esta que aparece vinculada à de progresso. E tal idéia, por sua vez, se prende à de soberania, no plano político Isto é, à idéia de que não existem mais "estados" ("états", ordens, estamentos) em contato e contrato entre si, mas o Estado, no qual o poder supremo é alocado a alguém (um indivíduo, ou uma assembléia), que é soberano na medida exata em que pode decidir qualquer assunto e, portanto. não apenas julgar, não só interpretar, - mas mudar tudo. A condição para a Revolução, para 1789, está na teoria da soberania ${ }^{(8)}$ : do Leviathan não sai apenas o Estado absoluto e o monarca absolutista, sai - mais até - o poder revolucionário e jacobino.

Estamos, é verdade, acostumados a pensar revolução e poder, Estado e revolução, como antagônicos. Mas o que não devemos esquecer é a cumplicidade que cada termo tem com seu par, estando ambos ancorados numa concepção política que rompe com a medieval: não há revolução que não centralize o poder. Basta recordarmos, em contraposição, a idéia medieval de que o mais importante é a iustitia - o que significa, por um lado, que nem o rei, o senhor mais alto, pode violá-la; por outro, que qualquer indivíduo, ou, melhor dizendo, qualquer magistrado, ainda que inferior, tem direito legítimo a agir em nome da iustitia, a legislar se falta uma lei justa. Ou seja: não há portador exclusivo do poder legítimo; e o Estado é concebido como composto de diversas instâncias, ou estamentos, ou ordens; cada uma delas tem o que é seu, o que lhe é peculiaf, e não pode ser privada disso sem seu próprio consentimento - é esta ordem harmônica a iustitia. Os Estados Gerais, quando são convocados em 1789, será para se reunirem com base nessa velha lei, que os divide em três assembléias, a examinar separadamente os assuntos; havendo divergência, prevaleceria o voto de duas, aliando clero e nobreza na vitória sobre o Terceiro Estado: mas a fusão dos três estados numa assembléia única, na qual os burgueses têm tantos deputados quanto os padres e nobres somados, determina uma nova política, o surgimento de um órgão que se torna supremo no Estado. E não é à toa que um dos principais pontos de tensão com o rei será, instalada a Assembléia Legislativa, a questão do veto: se uma assembléia expressa a vontade da nação, do povo, como pode ser limitada por outra vontade (que se reduz à vontade parti- 
cular, abusiva, usurpadora), como pode ela não ser soberana? A soberania é o pressuposto para haver revolução. É preciso conceber-se que existe um poder soberano - digamos, o do povo para que ele possa exprimir-se de forma revolucionária.

Deste ponto de vista, o principal não é pensar as revoluçōes como ocorreram - pois, afinal, o século XVII as conheceu, e muitas, embora manquées quase todas ${ }^{(9)}$ - mas como se tornam pensáveis. Por que, desde 1789, se concebe o acontecer histórico basicamente como revolucionário? É raro o político que não prometa, ainda hoje, em seu discurso, basicamente mudar, transformar; e, mesmo nas propagandas comerciais, a revolução, a ruptura, a transformação radical são promessas freqüentes. Revolução sexual, ou verde, ou agrícola, ou na maneira de se vestir, ou de guiar: o acontecer histórico que não inove parece, apenas, banal, torna-se negligenciável, deve ser ignorado. Retomando, então: para se constituir este nosso viés, alguns fatores se aliaram. Primeiro, uma nova noção do tempo, que não é mais algo que se dissipa, no reencontro com o divino ou com a natureza humana, porém passa a ser pensado como um diferenciador irredutivel. $O$ que depende de uma relativa laicização que se faz da história humana. Segundo, uma cor positiva que se dá ao tempo: progresso: e, terceiro, a soberania, que permite, da política, levar à idéia do tempo como instaurador de algo radicalmente novo. É somente com o fim da sociedade de ordens, e a concentraçāo da ordem a partir da soberania, que a inovação radical passa a ser valorizada. Notemos que agora se trata de inovação radical, não das "innovations", que os ingleses das revoluçōes do século XVII acusavam o rei de tramar, e que eram postas no plural apenas para acentuar o desdém que mereciam.

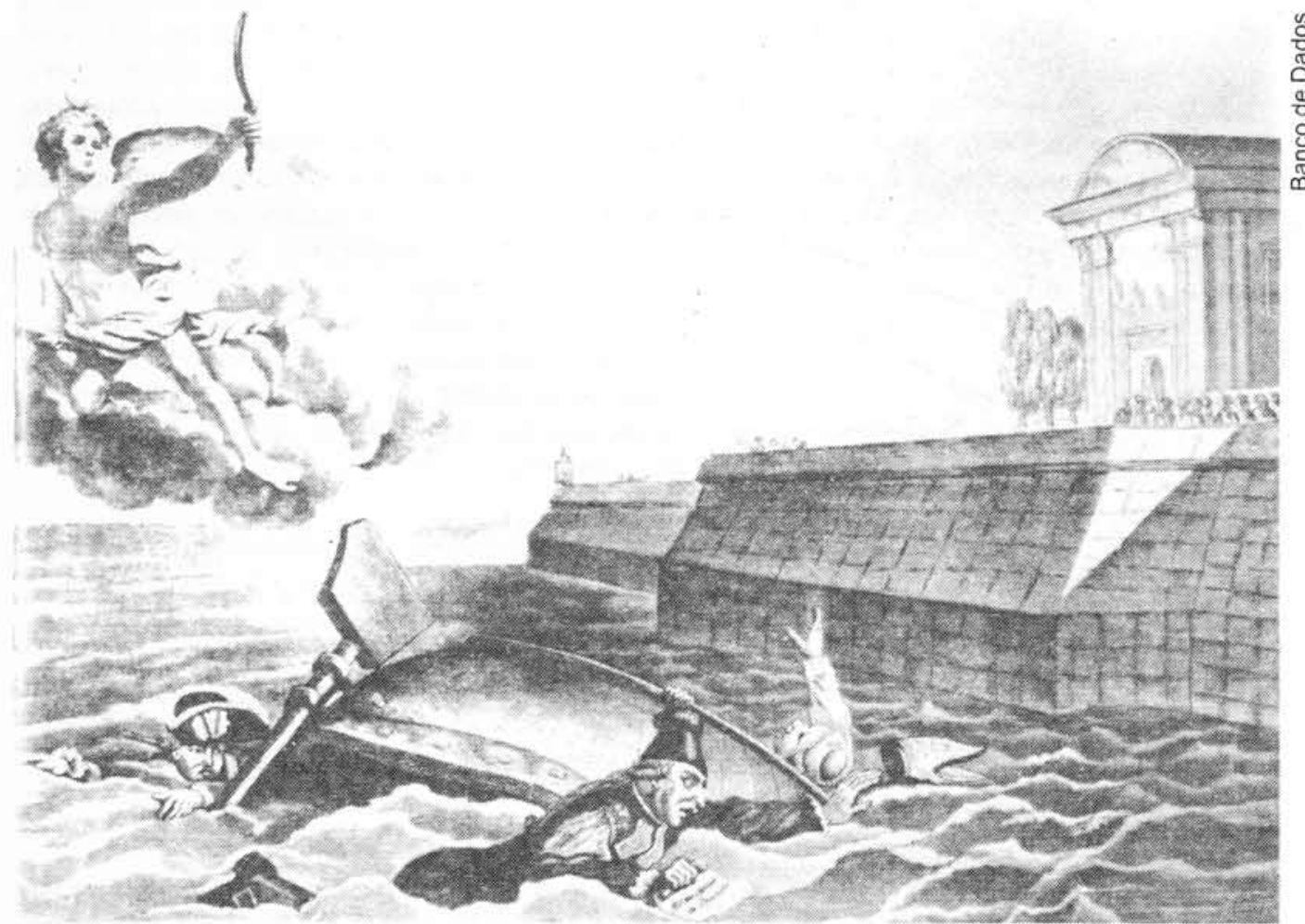

Quando 0 acontecer histórico passa a ser vivido como transformação, a história deixa de ser essa extensão da experiência que permitia aos moralistes um saber sobre o homem, compreendido como um saber moral. Entendamo-nos bem: moral no sentido que prevalece até começos do nosso século, antes de firmar-se a psicologia como ciência, e que representa uma fusão, ou hoje uma confusão, de duas acepções - a moral (substantivo) enquanto prescrição ditada à conduta humana, e o moral (adjetivo) enquanto campo oposto ao físico, cobrindo portanto o conhecimento da atividade mental humana enquanto gera tudo o que nos afasta da mera determinação física: conhecimento das paixōes, psicologia avant la lettre. O essencial, ainda, é que este conhecimento das paixōes e esta prescrição às ações se engatavam intrinsecamente. Leiamos La Bruyère ou La Rochefoucauld: entre o que dizem do homem (o moral) $€ 0$ que lhe aconselham (a moral), entre o homem como seu objeto e referente, e o homem como destinatário de seu discurso, entre a terceira e a segunda pessoa do discurso, entre o indicativo e o imperativo, a análise

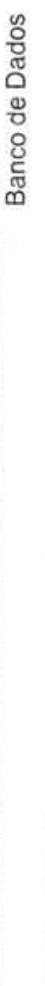

\section{O naufrágio das ordens privilegiadas - nobres, magistrados e clero - enquanto o espirito de Rousseau ilumina a Assembléia com a luz refletida da natureza}

(9) Para citar apenas algumas: a Fronda, parlamentar e dos príncipes, na Franca por volta de 1650: 1640 1640 s revoluçōes de Portugal e da $\mathrm{Ca}$ talunha, ambas buscando a indepen. dência da coroa espanhola, bem sucedida a primeira, mal a segunda; na Inglaterra, duas revoluçōes, uma na década de 1640 , outra em 1688 quela mais radical e terminando por uma restauraçăo da monarquia Stuart, esta última bem controlada pelas classes dominantes e por isso mesmo inaugurando um regime politico duradouro. 
e a norma, a passagem é constante, e a distinção, por vezes, difícil. Assim, se nos detemos nesse uso da história, anterior ao século XVIII, veremos que se trata propriamente de um uso: a história enquanto saber, enquanto ciência, conta relativamente pouco. $O$ importante é a moral que dela se destila; e por isso a história é, propriamente, um gênero literário. Posso extrair lições de Plutarco ou de Homero, de quem narra o que aconteceu, ou de quem fabula, desde que o faça com verossimilhança. A rigor conviria a essa história o que Aristóteles afirma na Poética, cap. IX: "A poesia é algo de mais filosófico e mais sério do que a história, pois [a poesia] refere principalmente o universal, e [a história] o particular. Por 'referir-se ao universal' entendo eu atribuir a um indivíduo de determinada natureza pensamentos e ações que, por liame de necessidade e verossimilhança, convêm a tal natureza" ${ }^{(10)}$. O que de fato aconteceu vale menos do que os princípios que produzem o acontecer em geral. E por isso o uso da história é, ele sim, um saber, melhor, uma mescla de saber com sabedoria. Nesta união se move o pensamento moraliste: na síntese de saber e sabedoria, de reflexão sobre o conhecimento e sobre a ação. O seu custo, no tocante à história, consiste em desconsiderá-la enquanto saber próprio, e reduzi-la a ilustração ou contraprova, ou seu maior mérito - a uma forma suplementar de experiência. A história é modo de descoberta, enquanto multiplica a experiência, ou de exposição, enquanto ensina. Dizê-la ciência seria, nessa época, excessivo.

Como então surge a moderna ciência histórica? A. Momigliano mostra que, até o século XVIII, distinguia-se a atividade do antiquário - que lidava com fontes primárias, de maneira crítica - e a do historiador - que fazia parte da retórica, e desdenhava a crítica de suas fontes. $O$ mesmo homem podia fazer as duas coisas, não importa: uma prática não interferia na outra. Pierre Bayle, antiquário, erudito, que submete todos os verbetes de seu Dicionário a crítica severa, quando escreve uma Vida de Gustavo Adolfo não se preocupa em apontar as fontes, adota estilo pomposo e impessoal, e limita-se à documentação mais oficial, sem compulsar nenhuma outra ${ }^{(11)}$. Teremos história no sentido que the damos, o de um saber, não o de simples material para a sabedoria e o saber, quando os historiadores adotarem os métodos elaborados pelos antiquários. George Huppert, porém, num livro precioso, The idea of perfect history, mostra como já no século XVI um grupo de historiadores franceses - Estienne Pasquier, Vignier, La Popelinière - utilizou os métodos críticos, apurados pelos juristas, para submeter as mais variadas fontes aos critérios rigorosos da prova. A história que eles fazem corresponde muito bem à posiçāo da noblesse de robe quinhentista, numa época em que ela consegue não estar dependente nem dos católicos nem dos huguenotes extremados - e por isso mesmo vai ser liquidada pelos jesuítas no século seguinte. Como dirá o padre Garasse, S.J., atacando em 1622 Pasquier:

"Quand vous raconterez quelquer histoire d'importance prise de Moyse, de Xenophon, de Caesar, de Thucydide, de Paul Emile, un impertinent vous dira froidement, cela est faux, vous vous trompez, il n'est pas ainsi que vous le dites, mon papier-journal \& Clopinel disent le contraire. Un impertinent, lors que vous direz que vous avez veu telle chose dans Pline, vous arrestera tout court, disant: $Y$ avez vous esté jamais? car i'ay esté moy; \& i'en puis parler comme tesmoing oculair, c'est une tresbelle ville" (o tal "impertinente", que Garasse desqualifica como ignorante, a pretexto de valorizar sua observação ocular confunde Plínio com uma cidade) ${ }^{(12)}$.

(10) Poética, cap. IX, p. 249 da segunda ediçăo da Abril Cultural, col. Os Pensadores.

(11) Cf. George Huppert, op. cit., pp. 179-80. Ver também o importante artigo de Arnaldo Momigliano, "L'histoire ancienne et l'Antiquaire", in Problèmes d'historiographie an cienne et moderne - Paris, Gallimard, 1983, pp. 244-93 -, d0 qu pard, partem tanto Huppert, na obra mencionada, quanto Paul Veyne, em seu Les Grecs croyaient-ils à leurs mythes?.

(12) [Garasse, S.J.], Les recherches des recherches et autres oeuvres de Me. Estienne Pasquier, 1622 (publ. anonimamente), cit. in Huppert, pp. 172-73.

(13) Pierre Mesnard, "Vers un portrait de Jean Bodin", in Oeuvres philosophiques de Jean Bodin, pp. vii-viii, Paris, 1951; cit. in Huppert, p. 175.
Recupera-se então a autoridade da citação, critério que os historiadores-magistrados haviam contestado; e, se procedimentos críticos se conservam entre o século XVI e o XVIII, é restringindo-se ao estudo da vida de santus (Mabillon), de fontes para a história medieval (Baluze), de moedas (Vaillant), e ainda à compilaçãc de glossários (Du Cange) ou dicionários (Bayle). É verdade que haverá continuidade de preocupação crítica, senão entre os escritores, pelo menos graças aos leitores - a essa massa de libertins, "homens (define Pierre Mesnard, desta vez com $s$, autor de um "Portrait de Jean Bodin") que souberam conservar o uso do espírito crítico nas questões políticas e religiosas bem no âmago do século XVII - na sua maior parte gens de robe, ... realistas, mas não servis, cristãos, porém com a maior liberdade de pensamento e até mesmo de expressão"(13).

Penso que uma razão mais deve ser proposta, para explicar porque essa historiografia quinhentista faliu, - mais profunda que a vitória católica, a repressão jesuítica ou o absolutismo de Luís XIV. É que, enquanto não há uma idéia de progresso, enquanto não há um tempo conotado positivamente - ou, pelo menos, enquanto não há uma identificação entre o tempo e a mudança 


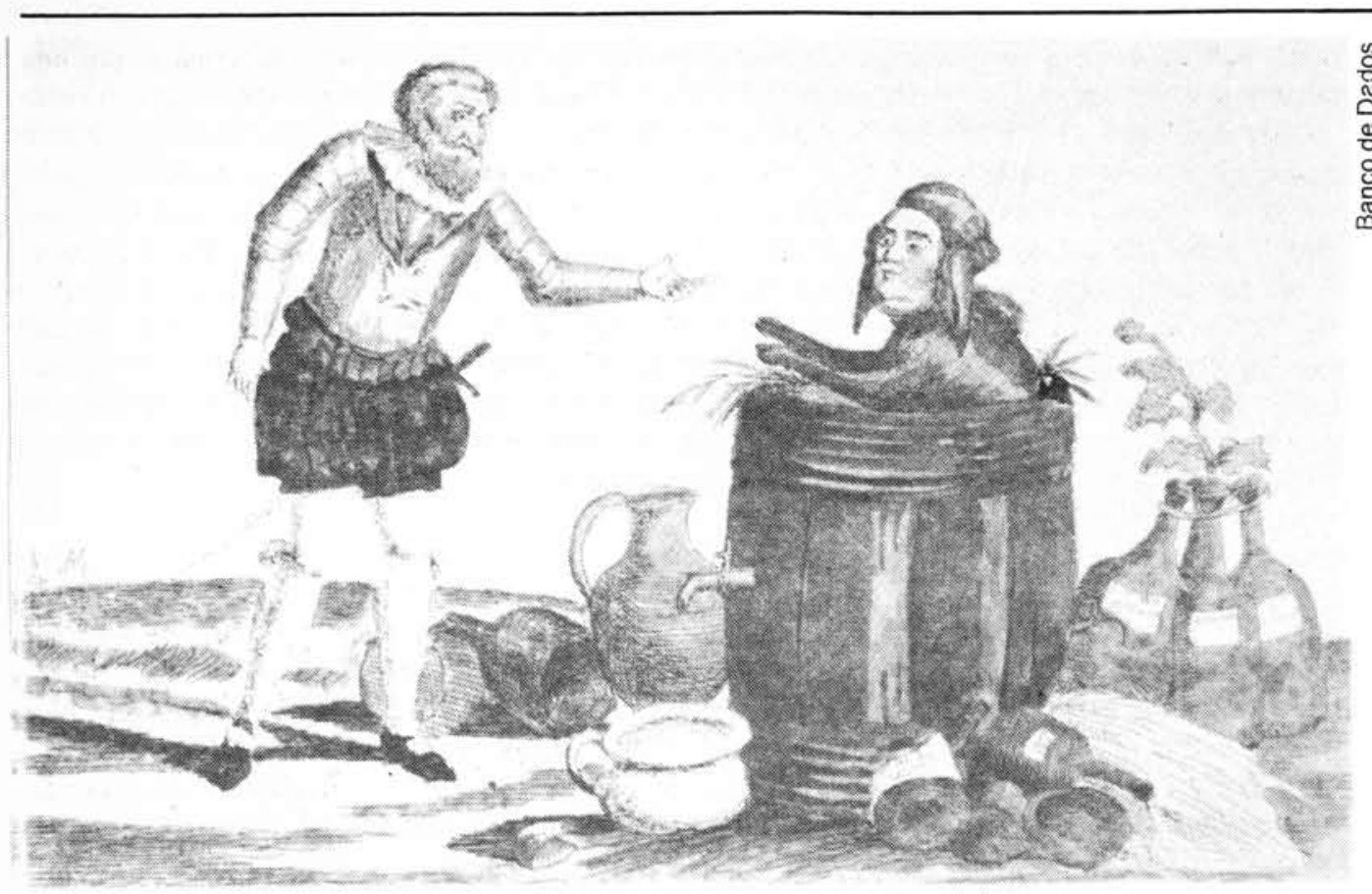

-, pouco ımporta se o que está se contando é verdade ou não. Importa apenas a lição que se vai tirar do relato (num plano moral mais restrito), ou o conhecimento que se vai ter do homem (num plano moraliste, refinado): por isso a fábula pode valer mais que a história autêntica. A autenticidade é questão de mera curiosidade, espécie de "Acredite se quiser" sofisticado. Assim, ao surgir uma história que pretenda ser ciência, quer analise a verdade dos fatos, quer estude os processos menos aparentes do que acontece, essa história deixará com isso mesmo de ser pedagógica. Em outras palavras, ao mudar o estatuto da história ela deixará de dar aula, e as famosas "liçōes da história" ficarão relegadas a um discurso que se tornou anacrônico, que não expressa mais o que se faz nos setores de ponta da disciplina. Aprender a história deixa de ser instrumento para aprender com a história: o segundo estudo se degrada, o primeiro se valoriza, e năo existe mais relação entre ambos. Com isso a história se revela autônoma, adquirindo campo próprio de inteligibilidade, linguagem e métodos rigorosos - não é mais uma experiência entre tantas, de vida, ou um discurso basicamente retórico, dirigido ao homme du monde, ou ao cortesão.

A condição para surgir tal história parece ser a de identificar o acontecimento, por exceiência, com a transformação - a instauração do novo. Assim foi, no século XVIII, que o passar do tempo deixou de ser meramente o lugar no qual se situam experiências, elas sim importantes, que permitiam entender o que é o homem - para tornar-se, ele próprio, objeto de conhecimento. $E$, com Isso, deixou de ser "passar do tempo". Notemos, por sinal, como se vai alterando uma perspectiva que é freqüente pelo menos até o século XVIII, a da identificação do tempo fugidio com a morte, a da melancolia ante as horas que se escoam, e os meses, e anos - para, em vez, ir nascendo uma crença maior no tempo, agora história, apontando o progresso: um otimismo, em escala da espécie, em dimensāo macro-humana (dimensão histórica), vencendo a atrabilis que era a do homem só e fadado à morte. Porque esse tempo do progresso, se excede a morte, em parte é porque excede as limitaçōes do indivíduo - em cuja esfera o fatum é um fato.

O principal será a inovação, geralmente considerada como positiva: é o otimismo de que falávamos, sócio do progressismo, portanto fortemente ancorado na maior parte dos pensadores de esquerda. Porém - e aqui está a dúvida, se ainda é possivel pensar o acontecer partindo da revolução -, até bem recentemente uma das condiçōes para tal inovação residia em ser ela bem identificável. É o que faz privilegiar-se o "grand soir", ou os "lendemains qui chantent", na esquerda francesa: num dia $x$, o mundo muda, pela ação concertada das massas que fazem a revolução. Ainda os marxistas, a quem repugna privilegiar na leitura da história o acontecimento, o factual (esclareçamos: na leitura que fazem do passado, leitura a posteriori, retrospectiva), ao dizerem o futuro fazem-no depender desse acontecimento por excelência, gigante, inaugural: a revolução. Distinguindo: há uma leitura marxista do passado e outra do futuro (senão em Marx, na prática dos revolucionários marxistas). O passado lê-se como ciência; nele agem leis, entre as
Caricatura popular mostrando o "bom" rei Henrique IV ao ver seu descendente Luis XVI transformado num porco 
quais sobressaem as da economia, o que obviamente não quer dizer uma determinação univoca de uma infra sobre uma superestrutura. Nele agem leis, e é pouca a consciência que o homem tem do que faz. Mas esta é a leitura do passado. Quando se vai pensar o futuro, do conhecimento passa-se à ação, - do que está feito, e portanto cientificamente requer que se considere como necessário, passa-se ao que está por fazer, e que supõe portanto a liberdade humana: se o passado é estudado por uma ciência, o futuro será lido por uma ética. Prevalecerá, então, a vontade. E em nenhuma linha marxista isso será tão nítido quanto no trotskismo, para o qual o imperativo ético da ação será até dito (pejorativamente) voluntarismo; ou no guevarismo ("O dever de todo revolucionário é fazer a revolução", dizia o Che, que n'A guerra de guerrilhas também afirma que os fatores "objetivos" necessários a uma revolução podem ser induzidos pela ação do grupo de revolucionários, com sua vontade moldando as circunstâncias); ou, ainda, no slogan trotskista francês de 15 anos atrás. "Une seule solution, la révolution".

Alguns pontos mais convém sugerir, se queremos prosseguir perguntando o que tornou possível pensar - e, claro, fazer - revoluçōes. A idéia de que um acontecimento (no sentido mais forte da palavra - quer o ato de um herói, para Carlyle, quer o processo revolucionário, para os marxistas) possa ser inaugural pressupõe um primado do artifício. Em outras palavras, se a história é feita pelos homens (como Marx resume, admiravelmente, uma noçăo-chave do pensamento pós-Revolução Francesa), o fato histórico é um feito, no qual a autoria humana está assinada. E onde o homem mais faz sua história, do que quando a muda por inteiro?

Ora, podemos ver que uma das linhas de força a marcar o pensamento político moderno, e isso desde o século XVII, desde os contratualistas, consiste na idéia de que a sociedade não é um dado natural, mas uma construção dos homens. Este, por sinal, é o sentido do contrato nas teorias que explicam por ele a formação do Estado - evidentemente os contratualistas não eram tolos a ponto de imaginar que um dia selvagens se reuniram para montar, a partir do quasenada, sem terem linguagem nem qualquer noção jurídica, uma estrutura complexa como a do Estado; o que eles enunciam, através do contrato, é que a vida social e política não chega ao homem já determinada, da natureza, mas é forjada por ele. Em palavras que o século XX celebrizou, seria dizer - com pequeno anacronismo - que a vida social do homem já não pertence à natureza, mas à cultura. Ou, simplesmente, que o homem social gera suas próprias formas de vida ${ }^{(14)}$.

Romper com a idéia de que a socialidade é natural foi, assim, condição para o homem, agora considerado faber de sua condição humana, ser capaz de conhecê-la e pensá-la. Foi também condição - mas aqui só necessária, não suficiente - para conceber que as sociedades se modifiquem radicalmente, na história. Se a sociedade não fosse artifício, feita pelo homem, não seria história. Revoluções são, ou foram, a obra humana por excelência.

Mas, daqui, não são poucas as questões que se colocam. O que é fazer? Pois esta é a pergunta que aparece, quando, primeiro com o contrato, depois com a revolução, $o$ acontecer histórico se identifica com o fazer por excelência. Fazer história significa dar primazia à consciência e à vontade, como quando se entende a revolução mediante o conhecimento de uma realidade e o planejamento de uma ação? Mas o termo generalizou-se, ampliou-se; e convém lembrar, aqui, - que diz Castoriadis sobre a revolução mais importante do século XX, a seu ver, a que mudou por completo a condição feminina, e que ocorreu através da junção de milhc̃es de combates, sem nenhum planejamento, muitas vezes sem nenhuma comunicação sequer entre si. Por aí vamos longe; o que aqui procurei levantar foram algumas questôes, que pode ser que fundamentem nossa concepção da história e da revolução, e que apontam, pelo menos, o paradoxo de que não há idéia moderna de revolução sem uma doutrina da soberania, nem haveria história como ciência

sem ter, como pressuposto, a idéia de revolução.

Castoriadis desenvolve de maneira interessante em seu Os Domínios do Homem (Paz e Terra, 1987). 